\title{
Pembuatan Video Profil Lembaga Penelitian dan Pengabdian Universitas Riau sebagai Media Promosi Berbasis Multimedia
}

\author{
Nita Rimayanti ${ }^{1}$, Ana Yulianti ${ }^{2}$, Belli Nasution ${ }^{3}$,Evawani Elysa Lubis ${ }^{4}$, \\ Jurusan Ilmu Komunikasi, Fakultas Ilmu Sosial dan Ilmu Politik, Universitas Riau ${ }^{1,3,4}$ \\ Teknik Informatika, Fakultas Teknik, Universitas Islam Riau \\ nita.rimayanti@lecturer.unri.ac.id'1 , ana.yulianti@eng.uir.ac.id,Belli.nasution@lecturer.unri.ac.id ${ }^{3}$, \\ Evawanielysalubis@gmail.com4
}

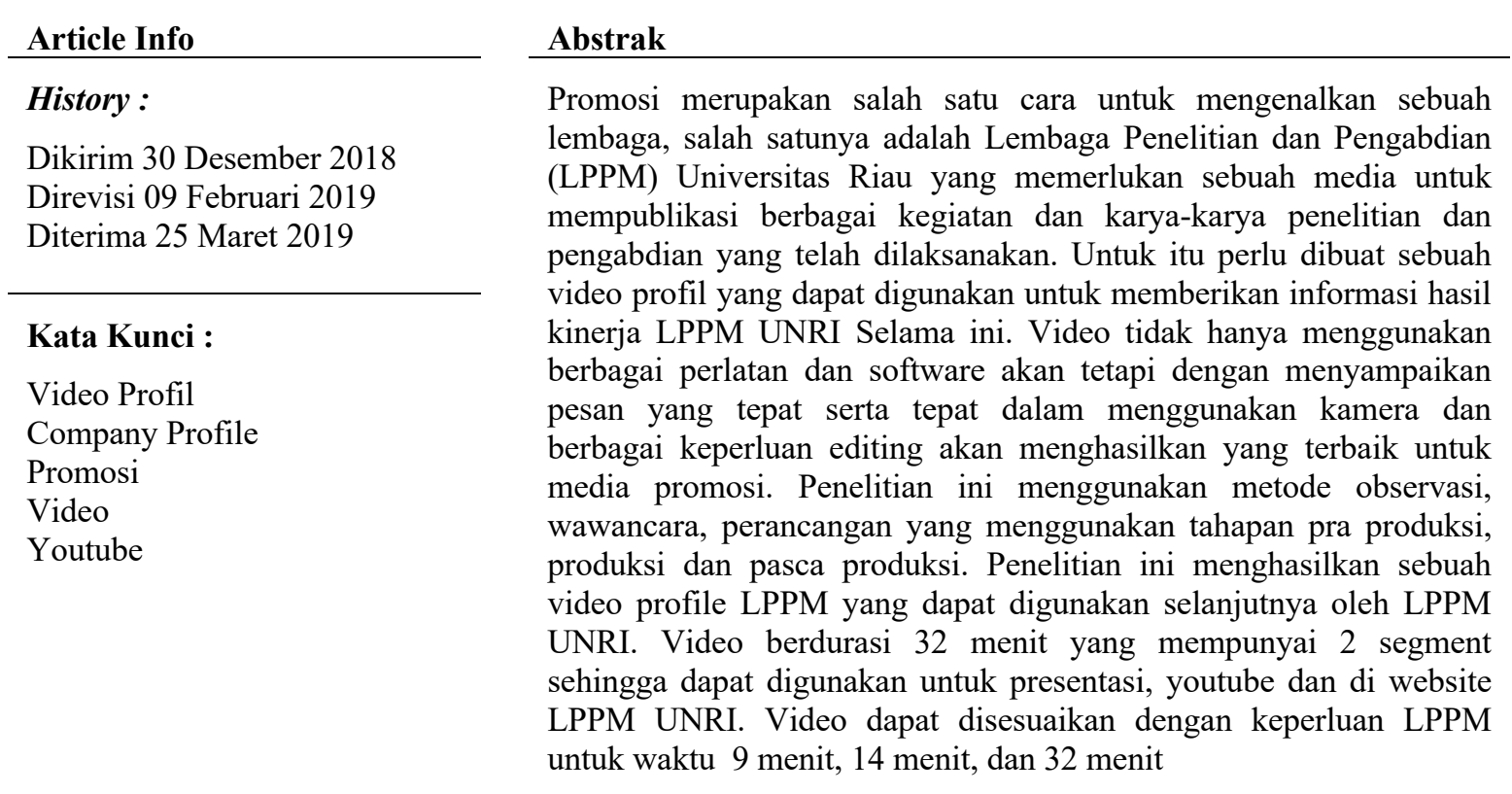

(C) This work is licensed under a Creative Commons AttributionShareAlike 4.0 International License.

\author{
Koresponden: \\ Nita Rimayanti, \\ Program Studi Ilmu Komunikasi, Fakultas Ilmu Sosial dan Ilmu Politik \\ Universitas Riau \\ Alamat Kampus Bina Widya Km 12,5 Simpang Baru Pekanbaru 28293 - Indonesia \\ Email : nita.rimayanti@lecturer.unri.ac.id
}

\section{PENDAHULUAN}

Institusi perguruan tinggi memiliki peran yang luas dalam pengembangan sumber daya manusia yang berkualitas. Perguruan tinggi mempunyai kewajiban untuk menyelenggarakan Tri Dharma Perguruan Tinggi yakni pendidikan, penelitian, dan pengabdian kepada masyarakat yang diharapkan dapat memberikan manfaat sebesar-besarnya bagi masyarakat, bangsa dan negara. Salah satu universitas yang berada di Kota Pekanbaru adalah Universitas Riau. Universitas Riau merupakan Universitas Negeri terbesar yang berada di Kota Pekanbaru. Oleh karena itu, sudah 
seharusnya Universitas Riau juga ikut terlibat aktif dalam melaksanakan Tri Dharma Perguruan Tinggi sehingga dapat memberikan kontribusi untuk meningkatkan kesejahteraan masyarakat Indonesia umumnya dan masyarakat Provinsi Riau khususnya.

Almadi syahza menyatakan bahwa salah satu lembaga yang mendukung tri dharma perguruan tinggi adalah lembaga yang melaksanakan kegiatan penelitian dan pengabdian di Universitas Riau adalah Lembaga Penelitian dan Pengabdian Universitas Riau yang disingkat LPPM UNRI. Lembaga ini merupakan unsur pelaksana yang melibatkan yang mempunyai tugas mengkoordinasikan, memantau, dan menilai pelaksanaan kegiatan penelitian dan pengabdian kepada masyarakat yang diselenggarakan oleh pusat - pusat di LPPM UNRI, Fakultas, jurusan, kelompok dan perorangan (Profil LPPM Unri, 2017).

Untuk melihat kinerja yang telah dilaksanakan oleh LPPM tentu memerlukan sebuah Profil. Profil LPPM yang dibuat selama ini berupa profil LPPM UNRI tahun 2017 yang dalam bentuk cetak untuk publikasi, akan tetapi dengan membuat profil yang memiliki unsur audio visual tentu menjadi lebih menarik, pesan tidak hanya melalui verbal saja tetapi juga pesan non verbal melalui gambar-gambar bergerak dan didukung oleh suara yang membuat profil tersebut serasa hidup. Untuk menciptakan sebuah keharmonisan antara kedua unsur tersebut diatas, dibutuhkan visualisasi dan audio yang tepat, terutama ditinjau dari siapa yang menjadi sasaran (khalayak) yang akan menjadi target dari pembuatan video profil.

Menyampaikan informasi melalui video profil akan lebih diperlukan instansi ataupun masyarakat apalagi dengan masuknya era informasi berbasis internet mau tidak mau media promosipun mengalami perubahan. Keberadaan internet sangatlah penting untuk menjadi bagian dalam menginformasikan capaian yang telah dihasilkan oleh LPPM UNRI serta menyampaikan rangkaian kegiatan yang telah dilaksanakan melalui audio visual. Saat ini LPPM sendiri telah menggunakan website untuk mengelola berbagai informasi oleh karena itu dengan adanya video profil LPPM UNRI akan dapat di upload ataupun diakses melalui website dan youtube LPPM UNRI sehingga menjadi sumber infomasi yang diperlukan oleh civitas Universitas Riau maupun pihak pemerintah dan swasta yang memerlukannya untuk menjadi pertimbangan dimanapun mereka berada.

Video profil perusahaan ataupun institusi merupakan media untuk menginformasikan hal-hal yang dianggap perlu bagi khalayak yang menjadi stakeholdernya. Informasi yang dimuat pada video profil sebuah perusahaan atau institusi tersebut dapat berupa prestasi-prestasi yang telah dicapai, kemampuan dari karyawan maupun karya-karya yang telah di ciptakan, selain itu juga mengenalkan bagaimana sejarah, visi dan misi dari perusahaan tersebut yang sesuai dengan apa yang dicapai oleh intansi ataupun lembaga seperti LPPM UNRI. Selanjutnya profil ini juga dapat menjadi media promosi sehingga lembaga LPPM UNRI dapat mengembangkan kerjasama dengan stakeholdernya lebih luas lagi. Untuk membuat sebuah video profil diperlukan perencanaan yang matang yang dimulai dari pra produksi, produksi dan pasca produksi. Kesiapan yang matang dapat menghasilkan sebuah video profil sesuai dengan keperlukan LPPM UNRI. Penyampaikan pesan yang tepat dengan menggunakan berbagai peralatan untuk produksi seperti kamera, sound, lighting dan editing yang baik maka dapat membantu mempromosikan berbagai informasi yang sesuai dengan target audiens. Kesalahan dalam menyampaikan pesan yang tidak tepat dapat membuat komunikasi tidak efektif. Video profil bisa dimaknai berbeda oleh orang lain ataupun target sasaran tidak tertarik untuk menonton video profil tersebut.

Penelitian sebelumnya telah dilakukan oleh beberapa orang seperti penelitian dari [4] mengenai pembuatan video profil Istana Mangkunegaran Surakarta Berbasis Multimedia. Hasil penelitiannya dalam membuat profil diperlukan sebuah perancangan yang meliputi storyboard, script dan rincian biaya yang digunakan agar proses produksi dapat berjalan lancar. Hasil video profil di masukkan kedalam VCD. Penelitian lainnya dari [6] mengenai Pembuatan Video Company Profile Berbasis Multimedia di Hotel Taman Sari Karanganyar Kabupaten Karang Anyar. Hasil Penelitiannya pembuatan video profil digunakan komputer berbasis multimedia sebagai media promosi Hotel Taman Sari Kabupaten Karanganyar.

Berdasarkan uraian diatas peneliti tertarik mengetahui bagaimana menghasilkan sebuah profil audio visual yang tepat sasaran. Adapun tujuan dari penelitian ini adalah untuk menghasilkan

Rimayanti, Pembuatan Video Profil Lembaga Penelitian dan Pengbadian Universitas Riau Sebagi Media Promosi berbasis Multimedia 
video profil Lembaga Penelitian dan Pengabdian Universitas Riau sebagai media promosi berbasis multimedia.

\section{METODE PENELITIAN}

Metode penelitian adalah cara dan langkah-langkah yang digunakan dalam melakukan penelitian. Pada penelitian dalam proses pengkajian aplikasi ini, cara dan langkah-langkah yang digunakan antara lain : Pengumpulan Data, Konsep Teori, dan Tahapan Perancangan Pembuatan Video Profil. Uraian penelitian yang digunakan dapat diuraikan sebagai berikut :

\subsection{Pengumpulan Data}

Dalam melakukan proses pembuatan aplikasi, sangat diperlukan sebuah data yang benar, dan terbukti keakuratannya. Maka dari itu, untuk mendapatkan data yang benar dan akurat, teknik pengumpulan data dilakukan dengan cara sebagai berikut :

1. Observasi

Observasi langsung dilakukan dengan cara melakukan kunjungan lapangan pada lokasi yang sedang diteliti dimana peneliti bisa mendapatkan gambaran yang relevan tentang kondisi baik sarana dan prasarana serta capaian - capaian yang telah dihasilkan oleh LPPM UNRI. Observasi dilakukan juga terhadap kinerja yang telah dilakukan oleh LPPM dan kegiatan-kegiatan baik berupa penelitian dan pengabdian yang dilaksanakan oleh dosendosen Universitas Riau.

2. Wawancara

Wawancara merupakan sumber informasi paling penting dalam mendapatkan data dan fakta lapangan. Peran informan sangat penting dalam hal ini, karena selain sebagai sumber data juga merupakan akses untuk mendapatkan informasi lanjutan. Pada penelitian ini, Peneliti melakukan wawancara dengan berbagai narasumber yang berkompeten di bidangnya. Wawancara dilakukan Ketua LPPM Universitas Riau, Sekretaris LPPM Universitas Riau, 1 Orang perwakilan dari Pusat Studi LPPM Universitas Riau dan dosendosen yang berkompeten dalam bidangnya dan telah menghasilkan produk penelitian dan pengabdian kepada masyarakat.

\subsection{Promosi}

Promosi merupakan elemen bauran pemasaran yang berfokus pada upaya menginformasikan, membujuk, dan mengingatkan kembali konsumen akan merek dan produk perusahaan [7].

\subsection{Company Profil}

Profil perusahaan di produksi untuk kepentingan institusi tertentu berkaitan dengan kegiatan yang mereka lakukan dan berfungsi sebagai alat bantu presentasi [3]. Company profile merupakan penjelasan mengenai sebuah perusahaan termasuk produknya secara verbal maupun grafik yang mengangkat nilai dari sebuah perusahaan termasuk produk serta keungulan dari perusahaan tersebut dibandingkan pesaingnya [8]. Produk atau jasa yang dihasilkan perusahaan dapat dicerminkan oleh faktor marketing mix, 7P, yaitu Product, Price, Promotion, Placement, people, process, dan physical evidence. Nilai dari perusahaan dapat dilihat dari Sejarah berdirinya sebuah perusahaan, visi dan misi, struktur organisasi, kinerja perusahaan dalam [8].

\subsection{Multimedia}

Multimedia adalah dari kata multi dan media. Multi berasal dari bahasa Latin yaitu nouns yang berarti banyak atau bermacam-macam. Sedangkan kata media berasal dari bahasa Latin, yaitu medium yang berarti perantara atau sesuatu yang dipakai untuk dan menghantarkan, menyampaikan atau membawa sesuatu. Berdasarkan itu multimedia merupakan perpaduan antara berbagai media (format file) yang berupa teks, gambar ( vektor atau bitmap), grafik, sound, 
animasi, video, interaksi, dan lain-lain yang dikemas menjadi file digital (komputerisasi), digunakan untuk menyimpan atau menghantarkan pesan kepada publik.

\subsection{Film}

Film adalah rekaman peristiwa daripada suatu kenyataan, karangan atau fantasi belaka. Image yang di hasilkan haruslah merupakan reproduksi kehidupan sesungguhnya atau suatu dunia pura-pura yang menyakinkan. Unsur visual dan audio visual daripada film perlu di integrasikan, hingga keduanya saling menunjang dalam mempengaruhi penonton [1].

Jenis-jenis film yang biasa diproduksi untuk berbagai keperluan terbagi atas 1) film dokumenter 2) film cerita pendek, 3) Film cerita panjang 4) film - film jenis lain yang diantaranya adalah profil perusahaan (company profile), Iklan Televisi, Program Televisi dan Video Klip. Perkembangan teknologi saat ini memungkinkan seseorang untuk melakukan shooting dengan format film, melakukan editing dalam format video dan menayangkan hasilnya dalam format film. Pada umumnya shooting dilakukan dengan film $35 \mathrm{~mm}$ dan diedit dalam format video menggunakan computer dan aneka perangkat lunak canggih. Para pembuat film pemula melakukan shooting dan editing dalam format video kemudian menayangkannya dalam format video atau film, $16 \mathrm{~mm}$ dan $35 \mathrm{~mm}[3]$.

\subsection{Video Profil}

Audio visual merupakan gabungan dari dua kata yaitu audio yang berarti suara dan visual yang berarti gambar, atau dengan kata lain menjelaskan, "Audio Visual adalah alat peraga yang dapat dilihat dan didengar dalam hal ini gambar yang bergerak menimbulkan suara" [2]. Menyiarkan nilai dari sebuah lembaga/intansi/perusahaan dapat melalui cetak maupun audio visual yang bisa disebut video profil. Secara umum dalam memproduksi audio visual dapat menggunakan tahap pra produksi, produksi, dan pasca produksi. Menurut [9] dalam proses produksi memilki beberapa tahapan yang harus dilakukan tahapan itu adalah pra produksi (perencanaan), produksi (liputan) dan pasca produksi (editing dan manipulating).

\subsection{Storyboard}

Storyboard adalah sebuah teknik shooting management. Disini dibuat daftar pengambilan gambar pada setiap adegan, dan divisualisasikan dalam bentuk sketsa gambar atau storyboard jika diperlukan [2].

\subsection{Perancangan}

Perancangan adalah tahap pembuatan spesifikasi mengenai arsitektur program, gaya, tampilan, dan kebutuhan material atau bahan untuk program. Tahap ini biasanya menggunakan storyboard untuk menggambarkan deskripsi tiap scene lain dan bagan alir (flowchart) untuk menggambarkan aliran dari satu scene ke scene lain [2]. Pembuatan video profil LPPM UNRI dilakukan dengan 3 tahap yaitu Pra Produksi, Produksi dan Pasca Produksi. Setelah video berhasil dibuat maka selanjutnya dilakukan evaluasi bersama ketua LPPM UNRI untuk menghasilkan kesamaan pemikiran dalam hasil video profil. Hal ini penting dilakukan untuk mencapai hasil terbaik sesuai dengan keperluan promosi LPPM UNRI. Tahapan perancangan pembuatan video profil LPPM UNRI ditampilkan pada gambar 1. 


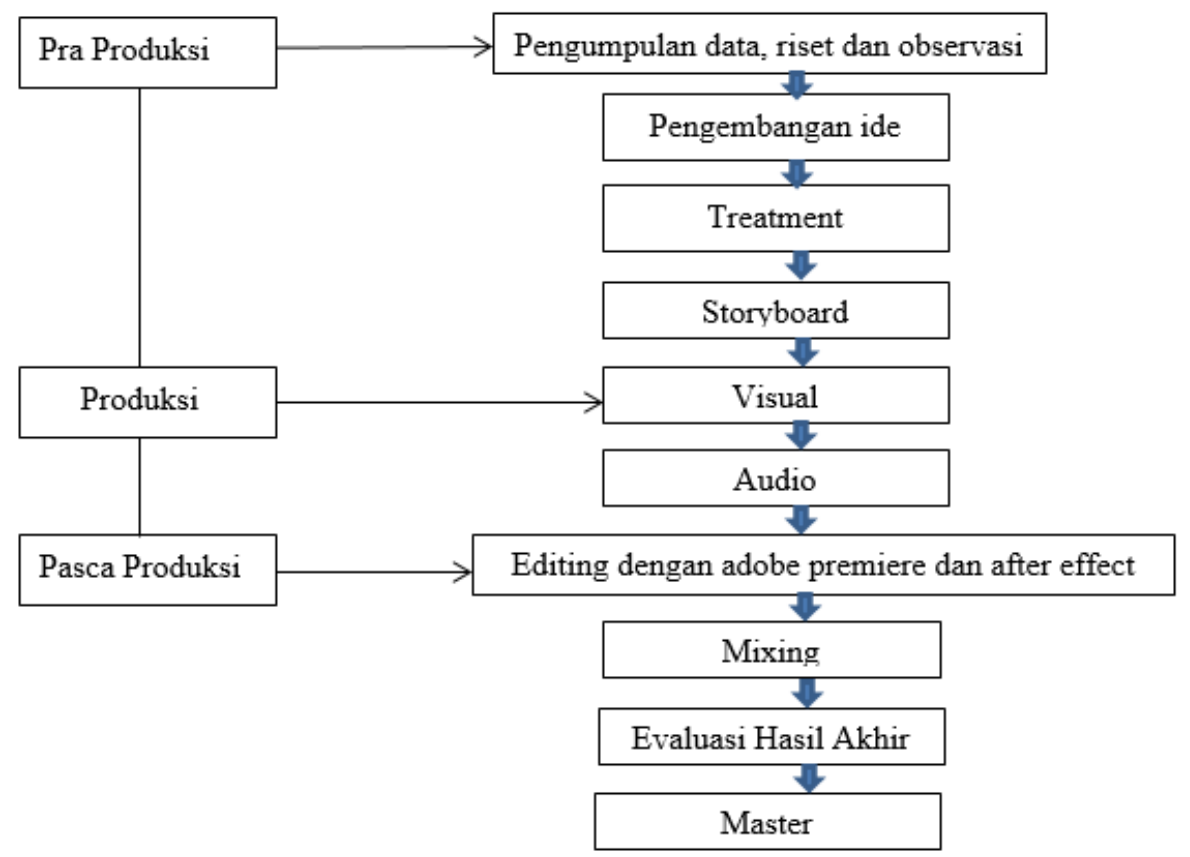

Gambar 1. Tahapan Perancangan Pembuatan video profil LPPM UNRI

\section{HASIL DAN PEMBAHASAN}

\subsection{Pra Produksi}

Dalam tahapan pra produksi dilakukan dengan observasi dan wawancara setelah itu dapat menghasilkan treatmen dan storyboard sebelum di produksi. Hasil dari dari pengumpulan data maka didapat pengembangan ide yang nantinya dapat tersampaikan pada penonton. Adapun hasil dari pengembangan data yang menghasilkan ide-ide sebagai berikut:

1. Tujuan dibuatnya video profil LPPM

Sebuah video profil dibuat dengan maksud dan tujuan yang disesuaikan dengan kebutuhan perusahaan atau institusi. Pembuatan video profil dari Lembaga Penelitian dan Pengabdian Universitas Riau ini bertujuan untuk:

a. Memperkenalkan kepada khalayak umum, tentang keberhasilan Lembaga Penelitian dan Pengabdian Universitas Riau menjadi lembaga yang mandiri dalam melaksanakan berbagai kegiatan penelitian dan pengabdian

b. Menginformasikan kepada masyarakat bagaimana kinerja LPPM universitas Riau selama ini dan apa saja produk-produk yang dihasilkan LPPM UR

c. Menginformasikan dan mempromosikan program kegiatan pengabdian kepada masyarakat keberhasilan dosen dan mahasiswa melalui Lembaga Penelitian dan Pengabdian Universitas Riau dalam melaksanakan penelitian dan pengabdian.

\section{Target audies video profil LPPM UNRI}

Sebuah video profil dibuat berdasarkan target audiens. Profil LPPM Universitas Riau ini dibuat untuk civitas akademika Universitas Riau dan juga stakeholder lainnya seperti lembaga pemerintah, perusahaan swasta, dan masyarakat yang memerlukan informasi dari lembaga LPPM UNRI.

\section{Product value LPPM UNRI}

Nilai dari LPPM Universitas Riau yang dapat dipublikasikan melalui video profil setelah observasi dan wawancara adalah hasil penelitian yang dilakukan oleh para dosen serta berbagai kegiatan pengabdian kepada masyarakat. Hasil dari kegiatan-kegiatan penelitian dan pengabdian ini dapat berupa buku referensi, buku ajar, artikel ilmiah yang diterbitkan pada jurnal nasional dan 
internasional yang terakreditasi, dan lain sebagainya. Publikasi yang semakin banyak dalam kuantitas dan kualitas yang semakin baik merupakan product value yang sangat penting bagi LPPM Universitas Riau. Hal itu dilakukan karena berdasarkan hasil wawancara dengan ketua Lppm Universitas Riau bahwa LPPM telah menjadi lembaga yang mandiri, dan wawancara tersebut juga dinyatakan didalam video profil lppm yang dibuat. Oleh karena itu bukti kemandirian LPPM dapat dilihat dari jumlah penelitian dan pengabdian yang telah dilakukan oleh dosen-dosen di Universitas Riau yang dapat dilihat dalam video profil mengenai hasil kinerja LPPM Universitas Riau dari tahun .

4. Media Ditayangkannya Video Profil

Dalam penelitian ini, dilakukan wawancara terlebih dahulu kepada pihak lembaga, sehingga diketahui media yang perlu untuk dilakukan promosi dengan membuat audio visual seperti Provil Video Company. Pada profil LPPM Universitas Riau yang berbentuk audio visual tersebut akan ditayangkan melalui layar televisi di kantor LPPM, kemudian juga diunggah pada website LPPM Universitas Riau serta YouTube. Selain itu promosi melalui video juga ditayangkan pada berbagai kegiatan baik di dalam Universitas Riau maupun kegiatan di Luar kampus. Pada saat ini penggunaan media sosial seperti website dan YouTube dipandang sangatlah penting oleh karena perkembangan pemanfaatan media social sebagai media informasi dan promosi dari perusahaan/institusi.

\section{Wawancara Dalam Video Profile}

Wawancara dalam video memberi kesan menyakinkan pada penonton, dalam produksi video profile juga ditentukan sipa yang akan diwawancarai. Penentuan orang-orang yang akan diwawancarai berdasarkan pada kemampuan selain itu juga ditentukan pimpinan LPPM yang akan diwawancara seperti ketua, Sekretaris dan perwakilan pusat studi LPPM UNRI.

6. Video Profil Yang Dibuat Menyampaikan Pesan

a. Menyampaikan kepada penonton bahwa lppm telah menjadi lembaga yang mandiri

b. Untuk memperlihakan kemandirian LPPM maka disampaikan melalui video bagaimana hasil-hasil penelitian yang telah dilakukan oleh dosen-dosen yang dananya didapat melalui bantuan dari LPPM, hasil ini berupa output yang dihasilkan dosen seperti jurnal-jurnal, buku, poster, bener, serta produk-produk yang dihasilkan dalam penelitiannya

c. Pada video ditampakkan bagaimana pelayanan yang dilaksanakan LPPM, ciri khas yang selalu sering di sampaikan adalah etos kerja, semangatnya civitas LPPM baik karyawan maupun pemimpin di lembaga LPPM bekerja dengan serius, keseriusan penting dilihatkan karena untuk menghasilkan unggulan dari penelitian dan pengabdian diperlukan keseriusan dan semangat dari staff maupun pemimpin LPPM. Hal ini juga ditularkan dalam keseriusan dosen untuk aktif dan bersemangat dalam kegiatan LPPM serta kerjasama pusat studi dalam menghasilkan berbagai kegiatan yang dapat meningkatkan kinerja LPPM.

d. Pelayanan yang diberikan oleh LPPM ada 3 yaitu kepada dosen, mahasiswa dan masyarakat maka didalam video penting sekali menyampaikannya kepada penonton bagaimana kegiatan-kegiatan yang dilaksanakan bersama dosen, mahasiswa dan masyarakat. Hal Ini tercermin juga dengan kegiatan antara dosen dengan mahaiswa dan masyarakat.

7. Treatment

Treatment pembuatan video profil Lembaga Penelitian dan Pengabdian Universitas Riau ditampilkan pada gambar 2 . 
Treatment Video Profil Lembaga Penelitian dan Pengabdian Universitas Riau

\begin{tabular}{|c|c|}
\hline Judul & : Profil LPPM UNRI \\
\hline Tujuan & $\begin{array}{l}\text { : Sebagai media Informasi mengenai pencapaian kinerja yang telah } \\
\text { dilakukan oleh LPPM UNRI }\end{array}$ \\
\hline Target Audiens & : Civitas Unri, masyarakat Umum \\
\hline \multicolumn{2}{|l|}{ Treatmen } \\
\hline \multicolumn{2}{|c|}{$\begin{array}{l}\text { - Logo Universitas Riau mengawali opening awal video profil LPPM, ditampakkan } \\
\text { berbagai kegiatan yang dilakukan oleh civitas LPPM selama ini. LPPM UNRI dibuka } \\
\text { dengan menampakkan sebuah animasi buku yang dibuka untuk memberi kesan } \\
\text { dimulainya video profil LPPM UNRI. Awal mulanya diperlihatkan wawancara ketua } \\
\text { LPPM UNRI yang menceritakan bagaimana berdirinya LPPM UNRI serta berbagai } \\
\text { kegiatan yang telah mereka hasilkan. Ketua LPPM menceritakan bagaimana LPPM } \\
\text { UNRI telah menjadi lembaga yang mandiri. Untuk memperkuat cerita dari ketua } \\
\text { LPPM ditampakkan berbagai video yang membuktikan hasil-hasil yang dicapai oleh } \\
\text { tenaga pengajar dalam penelitian dan pengabdian. }\end{array}$} \\
\hline \multirow{2}{*}{\multicolumn{2}{|c|}{$\begin{array}{l}\text { - Visi dan misi LPPM ditampakkan dalam teks yang bisa bergerak dengan warna lebih } \\
\text { banyak hijau. setelah disampaikan visi dan misi berceritalah salah satu dosen di UNRI } \\
\text { yang telah berhasil dalam melakukan penelitian baik pembuatan buku ajar, jurnal dan } \\
\text { paten. wawancara menjadi pendukung akan berhasilnya LPPM dalam mensukseskan } \\
\text { kinerja dosen dalam penelitian yang juga disampaikan dalam wawancara ketua LPPM } \\
\text { UNRI. }\end{array}$}} \\
\hline & \\
\hline \multicolumn{2}{|c|}{$\begin{array}{l}\text { - Layanan LPPM UNRI di sampaikan melalui teks yang bergerakkelanjutan setelah } \\
\text { disampaikannya layanan LPPM UNRI nampaklah dialog sekretaris LPPM UNRI yang } \\
\text { membahas program kegiatan LPPM UNRI. Karyawan diperlihatkan dalam berbaga } \\
\text { kegiatan dengan penampilan menarik dan ramah dalam melakukan pelayanan sehingga } \\
\text { nampaklah dalam kisah selanjutnya bagaimana struktur organisasi LPPM UNRI. }\end{array}$} \\
\hline
\end{tabular}

Gambar 2. Treatment video profil LPPM UNRI (Sumber : Olahan peneliti)

8. Storyboard

Storyboard Pembuatan Video Profil Lembaga Penelitian dan Pengabdian Universitas Riau ditampilkan pada gambar 3 .
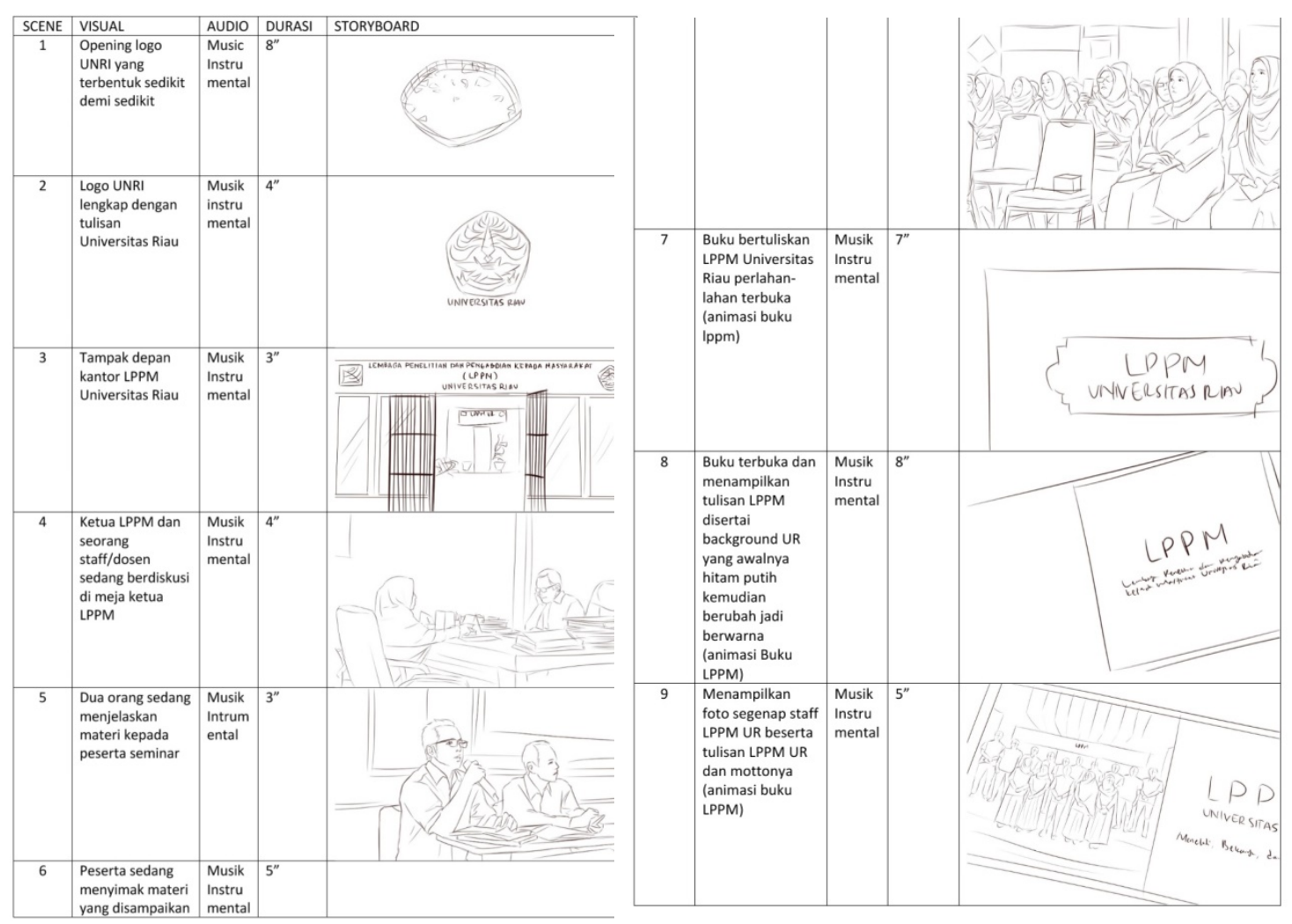

Gambar 3. Storyboard Video Profil LPPM UNRI (Sumber : Olahan Peneliti) 


\subsection{Produksi}

Persiapan fasilitas-fasilitas serta alat-alat pendukung dan tenaga-tenaga ahli dalam pembuatan video profil. Peralatan produksi yang digunakan adalah sebuah Kamera Sony NEX VG30 beserta Tripod Kamera, Screen tv, 2 Lighting (2x800Watt) beserta Stand Lighting, Record Audio, Microphones beserta Stand Boom Mic, Slider, Dolly dan alat-alat pendukung lainnya seperti beberapa kabel panjang, colokan. Selain itu juga ada property lain yang mendukung dalam produksi video profile.

Berdasarkan perencanaan yang dilakukan maka hasil video yang dibuat sampai tahap pascaproduksi maka target yang ingin dicapai dapat dilaksanakan dalam memproduksi video yang berdurasi 32 menit ini adalah :

1. Menyampaikan kepada penonton bahwa LPPM telah menjadi lembaga yang mandiri, hal ini disampaikan melalui wawancara dnegan ketua LPPM universitas Riau melalui wawancara

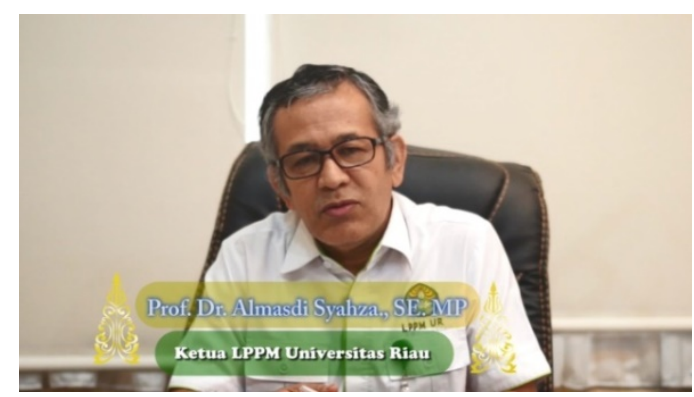

Gambar 4. Wawancara Dengan Ketua LPPM

(Sumber : Hasil Audiovisual LPPM Universitas Riau)

2. Untuk memperlihatkan kemandirian LPPM maka disampaikan melalui video bagaimana hasil-hasil penelitian yang telah dilakukan oleh dosen-dosen yang dananya didapat melalui bantuan dari LPPM, video berupa output yang dihasilkan dosen seperti jurnal-jurnal, buku, poster, bener, serta produk-produk yang dihasilkan.

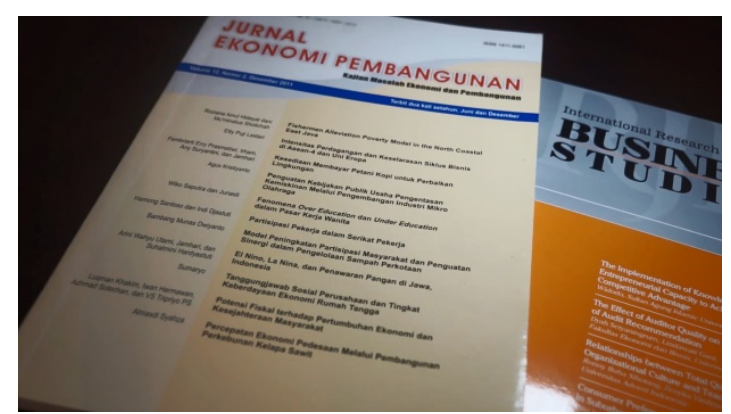

Gambar 5. Output Jurnal Yang Dihasilkan Oleh Dosen-Dosen

(Sumber : Hasil Audiovisual LPPM Universitas Riau) 


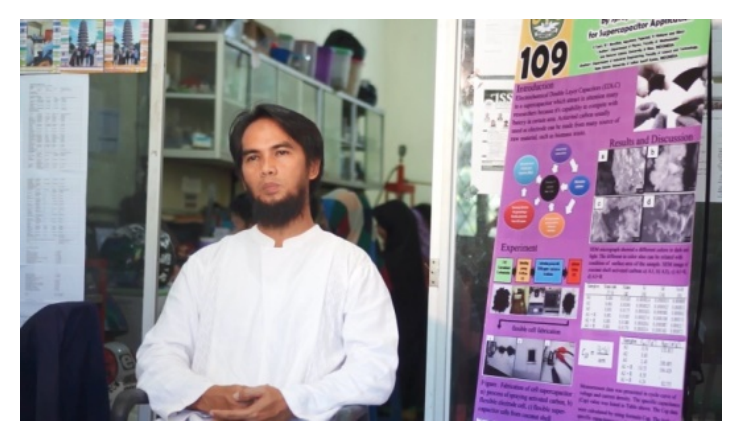

Gambar 6. Output Bener Dosen

(Sumber : Hasil Audiovisual LPPM Universitas Riau)

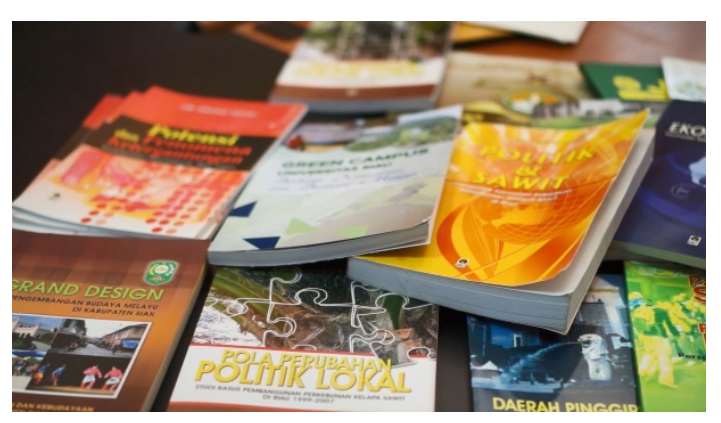

Gambar 7. Output Buku Dosen-Dosen

(Sumber : Hasil Audiovisual LPPM Universitas Riau)

3. Pada video ditampakkan bagaimana pelayanan yang dilaksanakan oleh civitas LPPM, ciri khas yang sering ditampakkan dalam video adalah etos kerja. Jansen Sinamo merumuskan tentang etor kerja yang merupakan seperangkat perilaku positif yang didasari pada keyakinan kuat dan disertai dengan komitmen yang serius dari paradigm kerja tertentu. Menurutnya, setiap manusia memiliki spirit untuk sukses, ruh keberhasilan, yang isa dalam bentuk motivasi murni untuk meraih dan menikmati keberhasilan. Sehingga bentuk-bentuk perilaku dapat seperti kerja keras, disiplin, teliti, tekun, integritas dan bertanggung jawab dalam pekerjaannya [5]. Berdasarkan etos kerja tersebut maka video yang dihasilkan digambarkan bagaimana ketelitian karyawan dalam bekerja, keseriusan melakukan pekerjaan dan semangat dari karyawan dalam bekerja. semangatnya civitas LPPM baik karyawan maupun pemimpin di lembaga LPPM bekerja dengan serius, keseriusan dan memberikan pujian akan keberhasilan bawahan dalam bekerja penting dilihatkan untuk memperlihatkan budaya kerja di LPPM yang baik dan kompak seperti dalam gambar dibawah ini : 


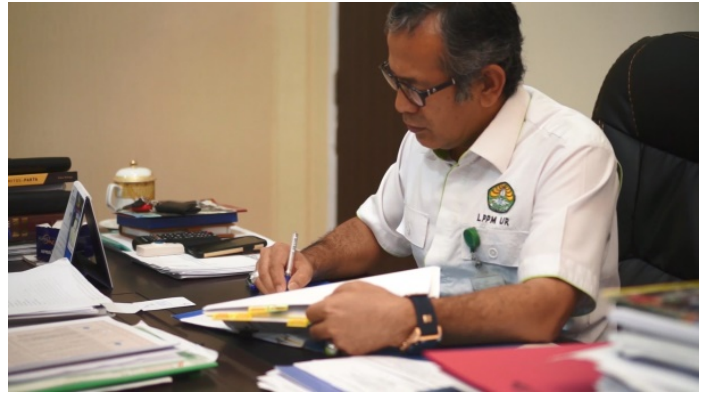

(a)

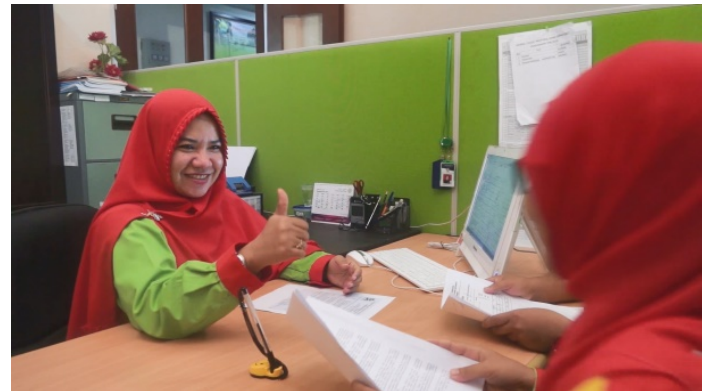

(c)

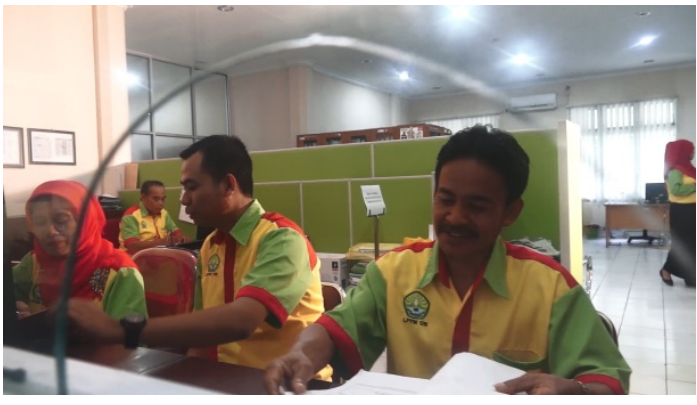

(b)

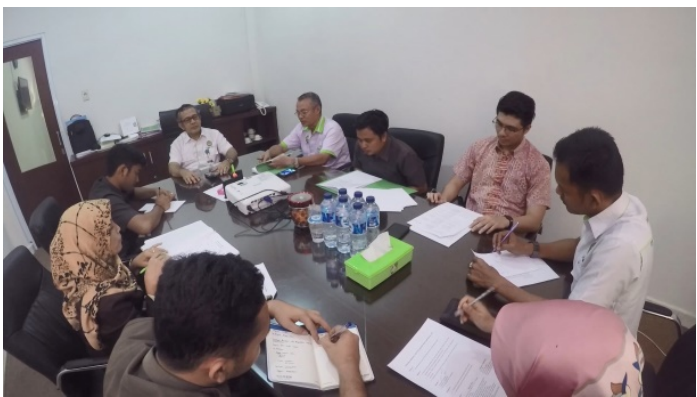

(d)

Gambar 8. Etos kerja yang ditampakkan dalam video (a)(b)(c)(d)

(Sumber Hasil Produksi di LPPM Universitas Riau)

Kegiatan - kegiatan yang dilakukan oleh LPPM Universitas Riau, etos kerja tidak hanya ditampakkan dari pimpinan dan staff LPPM Universitas Riau juga dilihat dari kegiatankegiatan yang dilakukan oleh LPPM bagaimana keseriusan dosen-dosen untuk mengikuti kegiatan tersebut, mereka bersemangat untuk mendapatkan informasi yang disampaikan oleh LPPM Universitas Riau. Pesan-pesan yang disampaikan bagaimana lembaga yang mandiri dalam melaksanakan berbagai kegiatan penelitian dan pengabdian.

4. Pelayanan yang diberikan oleh LPPM ada 3 yaitu kepada dosen, mahasiswa dan masyarakat maka didalam video penting sekali menyampaikannya kepada penonton bagaimana kegiatan-kegiatan yang dilaksanakan bersama dosen, mahasiswa dan masyarakat.

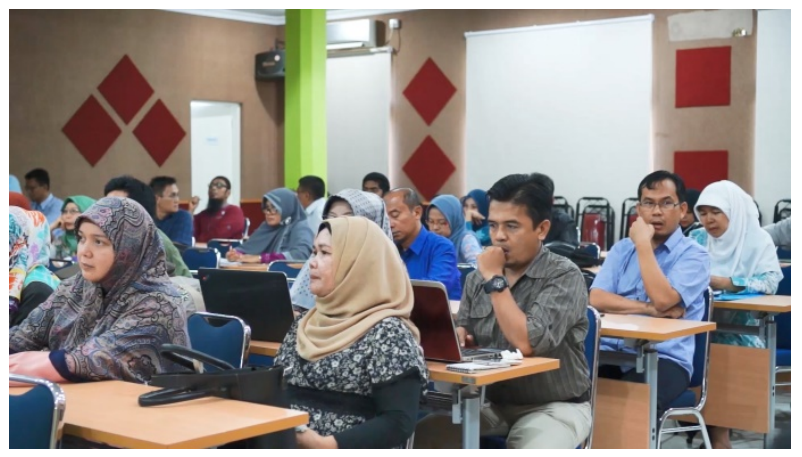

Gambar 9. LPPM Bersama Dosen-Dosen

(Sumber : Hasil Audiovisual LPPM Universitas Riau) 


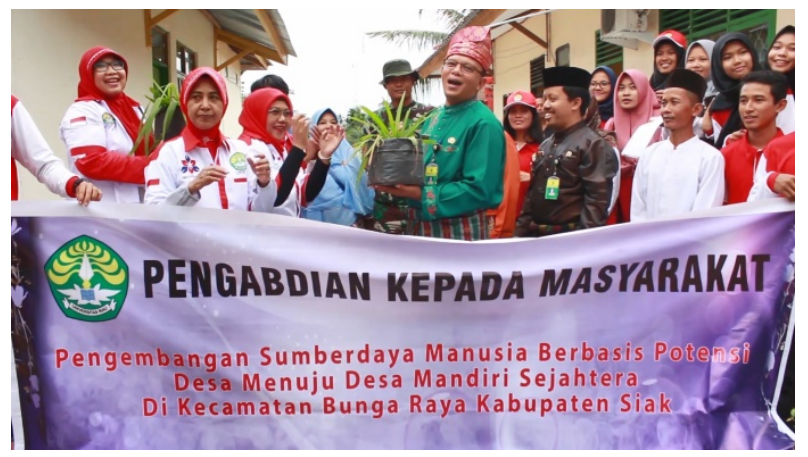

Gambar 10. Kegiatan Dosen Bersama Masyarakat (Sumber : Hasil Audiovisual LPPM Universitas Riau)

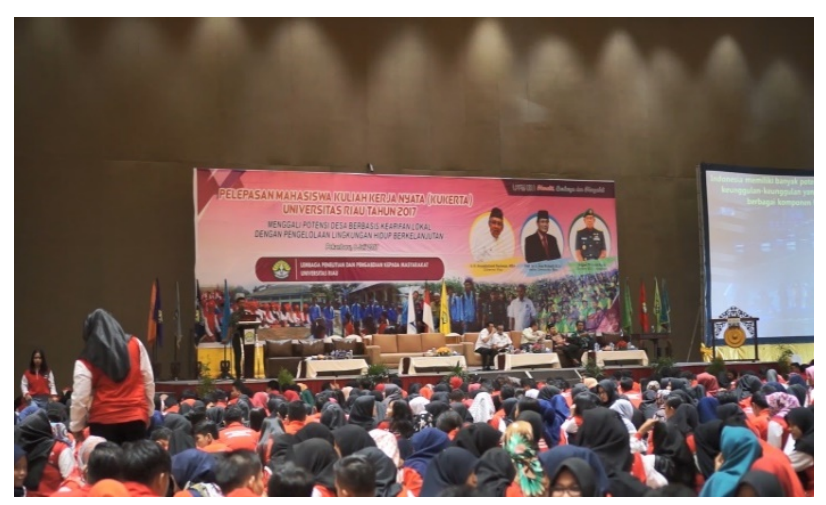

Gambar 11. Kegiatan Bersama Mahasiswa

(Sumber : Hasil Audiovisual LPPM Universitas Riau)

\subsection{Pasca Produksi}

Pada proses editing menggunakan 1 unit personal komputer dan laptop, dalam tahap ini juga proses dilakukan dengan menggunakan Software Adobe Premiere Pro CC 2015 untuk proses editing/penyuntingan Video dan Audio, Adobe After Effect Pro CC 2015 untuk pembuatan efek Grafis, dan Adobe Photoshop CS3. Selain itu dalam video juga dihasilkan effek-efek untuk memberikan keindahan dalam video, terutama opening LPPM yang berbentuk buku dan sangat pas dengan keseluruhan video yang menampakkan karya-karya dalam penelitian dan juga dapat menghasilkan buku-buku maupun jurnal penelitian. Video tersebut dibuat melalui software after effect. Strategi untuk mengurangi kebosanan karena banyaknya wawancara dengan membuat 2 segment menjadi 3 video dalam video yaitu segment pertama menceritakan secara singkat tentang lppm, segment kedua selain cerita lppm di sequen pertama juga ditambahkan bagaimana hasil yang dicapai oleh LPPM dan pusat studi yang ada di LPPM. Dua segment dapat dipisah menjadi dua dan satu lagi video full keseluruhan mengenai penelitian-penelitian yang dilakukan oleh dosen-dosen Universitas Riau untuk ditempatkan di media televise yang berad di depan pintu masuk LPPM UNRI. Setelah video dan audio digabungkan. Video yang sudah selesai di presentasikan kepada ketua LPPM untuk mengevaluasi hasil proses produksi dan editing. Perbaikan dilakukan 1 kali dan selanjutnya di simpan dalam bentuk MPEG4 yang dimasukkan kedalam dvd sehingga tampil cantik. 


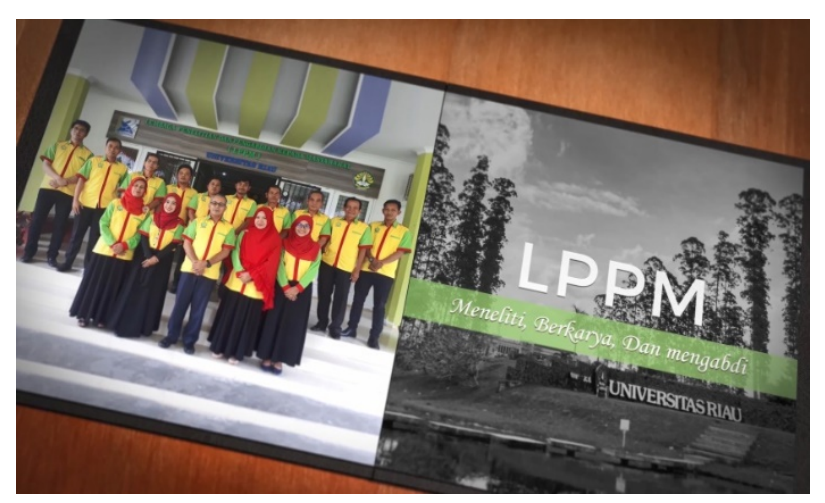

Gambar 12. Desain Buku Dalam Video Dengan Software Affter Effect

(Sumber : Hasil Audiovisual LPPM Universitas Riau)

\section{KESIMPULAN}

Telah dihasilkan sebuah video profile LPPM yang dapat digunakan selanjutnya oleh LPPM UNRI. Video berdurasi 32 menit yang mempunyai 2 segment sehingga dapat digunakan untuk media presentasi, youtube dan di website LPPM UNRI. Video dapat disesuaikan dengan keperluan LPPM untuk waktu 9 menit, 14 menit, dan 32 menit.

\section{UCAPAN TERIMA KASIH}

Penulis mengucapkan terima kasih kepada LPPM Universitas Riau yang telah memberi dana penelitian melalui skema dosen muda terkhusus ketua LPPM UNRI Prof.Dr. Almasdi Syahza, SE,MP selaku Ketua LPPM UNRI.

\section{DAFTAR PUSTAKA}

[1] Joseph V. Mascelli, A.S.C, "The Five C's Of Cinematography", California, Jakarta:Proyek Terjemahan Yayasan Citra, 1986.

[2] Astriyani, E, Dkk, "Media Video Company Profile Sebagai Sarana Informasi Dan Promosi Di Pt. Surya Toto Indonesia Tbk. Kabupaten Tangerang", Jurnal CICES ISSN: 2356-5209, Vol. 2 No. 2, 2016.

[3] Effendy, Heru, "Mari Membuat Film", Jakarta: Penerbit Erlangga, 2009.

[4] Hidayati, D, "Pembuatan Video Profil Istana Mangkunegaran Surakarta Berbasis Multimedia", Journal Speed, ISSN : 2088-0154, Volume 2 No. 1, 2010.

[5] Mulyadi, Acep. 2008. Islam dan Etos Kerja : Relasi Antara Kualitas Keagamaan dengan etos Produktivitas Kerja di Daerah Kawasan Industri Kabupaten Bekasi. Jurnal Universitas Islam 45 Bekasi Vol 4 No. 1.

[6] Taufika, A, " Pembuatan Video Company Profile Berbasis Multimedia Di Hotel Taman Sari Karanganyar Kabupaten Karanganyar", Seminar Riset Unggulan Nasional Informatika dan Komputer FTI UNSA 2013, Vol 2 No 1, ISSN: 2302-1136, 2013.

[7] Tjiptono, F, "Strategi Pemasaran Edisi 4", Yogyakarta:Penerbit Andi, 2014

[8] Setiawan, Ridho Alvin, "LKP : Rancang Bangun Company Profil Berbasis Web Pada PT. Javastone Perkasa". Undergraduate thesis, Institut Bisnis dan Informatika Stikom Surabaya, 2015.

[9] Rachman, Abdul, “Dasar- Dasar Penyiaran”, Pekanbaru, Witra Irzani, 2009. 